\title{
Screening Tomato Seedlings for Resistance to Bacterial Spot
}

\author{
G. Cameron Somodi, J.B. Jones, J.W. Scott, and J.P. Jones \\ University of Florida, Gulf Coast Research and Education Center, 5007 60th \\ Street East, Bradenton, FL 34203
}

Additional index words. Xanthomonas campestris pv. vesicatoria, Lycopersicon esculentum

\begin{abstract}
A 'spray-inoculation seedling screening procedure was developed for detecting resistance to Xanthomonas campestris pv. vesicatoria (Doidge) Dye, causal agent of bacterial spot of tomato (Lycopersicon esculentum Mill.). Two-week-old transplants were preconditioned under $95 \%$ humidity for 16 hours before spray inoculation and then rated for bacterial spot 2 weeks later. Resistant plants could also be distinguished from susceptible genotypes using a modified bacterial speck [Pseudomonas syringae pv. tomato (Okabe) Young, Dye, and Wilkie] screening procedure (cotyledon-dip technique). When results of both screening methods were compared to field ratings from three previous seasons, significant correlations were more frequently observed for the spray-inoculation method. In Summer 1991, individual plants were evaluated by the spray-inoculation technique and then were placed in the field to determine susceptibility under field conditions. Correlations $(r=0.28$ to 0.34$)$ between spray-inoculation seedling screening ratings and field ratings, although low, were significant $(P \leq \mathbf{0 . 0 0 0 1})$. More than $90 \%$ of susceptible plants could be eliminated, saving labor, space, and time.
\end{abstract}

Bacterial spot of tomato is prevalent under moist, warm conditions in tropical and subtropical tomato-growing areas. Control of this disease by manipulating cultural practices and chemical protestants is often ineffective (Conover and Gerhold, 1981; Marco and Stall, 1983; Stall and Thayer, 1962; Thayer and Stall, 1962). Before 1986, partial bacterial spot resistance was found in various genotypes (Coyne and Schuster, 1967; Crill et al., 1972; Lawson and Summers, 1984). However, there has been some skepticism about incorporating partial resistance into commercial lines (Crill et al., 1972; Volin, 1979). Since the initial report of a high level of bacterial spot resistance in 1986 (i.e., Hawaii 7998), there has been hope that the incorporation of Hawaii 7998 resistance into commercial varieties will offer genetic control (Scott and Jones, 1986).

An accurate greenhouse or growth-chamber technique for screening genotypes would lessen the need for large-scale field screening. Various techniques have been evaluated for their potential efficacy as screening methods (Coyne and Schuster, 1967; Lawson and Summers, 1984; Russell, 1992; Scott et al., 1989; Volin, 1979). Although measuring bacterial populations in lesions by direct plate count and by indirect immunofluorescence was effective (Somodi et al., 1989, 1990), both are

Receivedforpublication12July 1993. Accepted for publication 13 Dec. 1993. Florida Agricultural Experiment Station Journal series no. R-03301. This research was supported in part by the U.S. Dept. of AgricultureunderCooperative State Research Service Special Grants no. 89-34135-4572 and no. 92-34135-7283, managed by the Caribbean Basin Advisory Group. The cost of publishing this paper wasdefrayedinpartbythepayment of page charges, Underpostal regulations, this paper therefore mus be hereby marked advertisement solel $y$ to indicate this fact. not practical for large-scale use. Thus, we initiated studies to identify a screening method or methods that would differentiate genotypes on a large scale with accuracy similar to field tests. A spray-inoculation seedling screening procedure was developed for differentiating genotypes with various levels of resistance derived from Hawaii 7998. This procedure and an adaption of a cotyledon-dip screening technique developed for bacterial speck resistance (Emmatty et al., 1982) were compared to field disease severity ratings.

\section{Materials and Methods}

Spray-inoculation seedling screening technique. The tomato genotypes possessing varying levels of resistance to $X$. c. vesicatoria used in these studies were 'Waker' [susceptible (S)], 'Sugar' (S), 'Lyconorma' (S), 'Campbell 28' [partially resistant (PR)], Ohio 4013-3 (PR), Florida 317 and 325 [resistance (R) derived from Hawaii 7998], and Hawaii 7998 (R). Seed of the genotypes were sown in Black Beauty spent coal (Reed Minerals Div., Highland, Ind.) in flats and covered with a 0.5 $\mathrm{cm}$ layer of vermiculite. Seedlings were transplanted into Todd planter flats (cell size, 3.8 $\mathrm{cm}^{3}$ ) (Speedling, Sun City, Fla.), which had been cut into thirds and filled with a soil mix composed of 1 vermiculite : 1 Canadian peat ( 0.03 m': 0.03 m') amended with 105 g superphosphate, $200 \mathrm{~g}$ dolomite, and $52 \mathrm{~g}$ hydrated lime. One row of each genotype was randomly placed in each flat. There were five replications of each genotype in experiments with two preconditioning treatments and four repli cations in experiments comparing four preconditioning treatments. Each replication consisted of five plants. Plants were arranged in a randomized complete-block design and were grown for 2 to 3 weeks (the fourth-leaf stage) on a greenhouse bench before treatment.
A wooden frame was constructed to fit on a solid bench in a walk-in growth chamber. In all studies the growth chamber was maintained at $28 \mathrm{C}$ with 12 -h days $\left(110 \mu \mathrm{mol} \cdot \mathrm{m}^{-2} \cdot \mathrm{s}^{-1}\right)$ and $>90 \%$ relative humidity $(\mathrm{RH})$. The frame was covered with 0.15 -mm-thick polyethylene and used as a mist chamber. One or two 5-liter cool-mist room humidifiers (Devilbiss Co., Toledo, Ohio) were placed in the mist chamber and were run $\approx 4 \mathrm{~h}$ before plants were placed in the enclosure. Plants were preconditioned by placing the flats containing the seedlings into the mist chamber and misting continuously for $\mathrm{O}, 8,16$, or $24 \mathrm{~h}$ before inoculation in two experiments, and for $\mathrm{O}$ or 16 $\mathrm{h}$ before inoculation in five experiments. The plants were exposed to $>95 \% \mathrm{RH}$ during this period and had free water standing on them at the end of the preconditioning period.

Inoculum was prepared by growing $X . c$. vesicatoria strains for $48 \mathrm{~h}$ on nutrient-yeastdextrose-agar plates at 28C (Jones et al., 1981). Bacterial cells were suspended in $0.01 \mathrm{M}$ $\mathrm{MgSO}_{4} \cdot 7 \mathrm{H}_{2} \mathrm{O}$ and adjusted to $\approx 10^{8} \mathrm{cfu} / \mathrm{ml}$ using a spectrophotometer. Plants were then inoculated with $\approx 30 \mathrm{ml}$ of a suspension of $X$. $c$. vesicatoria per one-third planter flat and placed in the growth chamber. About 12 days after inoculation, plants were individually rated for bacterial spot severity using the HorsfallBarratt scale (Horsfall and Barratt, 1945), where $1=0 \% ; 2=0 \%$ to $3 \% ; 3=3 \%$ to $6 \% ; 4$ $=6 \%$ to $12 \% ; 5=12 \%$ to $25 \% ; 6=25 \%$ to $50 \% ; 7=50 \%$ to $75 \% ; 8=75 \%$ to $87 \% ; 9=$ $87 \%$ to $94 \% ; 10=94 \%$ to $97 \% ; 11=97 \%$ to $100 \%$; and $12=100 \%$ diseased tissue.

Cotyledon-dip seedling screening technique. The technique of Emmatty et al. (1982), developed for screening for bacterial speck resistance, was modified. Seed of 'Walter', 'Lycononna', 'Sugar', 'Campbell 28', Ohio 4013-3 (PR), Walter $\times$ Hawaii 7998 (S x R), Florida 317 and 325, and Hawaii 7998 were sown in spent coal and placed in the greenhouse. Ten days later, aerial portions of the plants were immersed for 15 min in $10^{8}$ or $8 \times$ $10^{8} \mathrm{cfu}$ of $X$. c. vesicatoria $/ \mathrm{ml}$ in a preliminary experiment and in $108 \mathrm{cfu} / \mathrm{ml}$ in seven experiments, with the inoculum prepared as described previously. Inoculated seedlings were then transplanted to Todd planter flats and placed in a growth chamber as described previously. There were five replications, with five plants of each genotype per replication. About 12 days after inoculation, plants were rated on the following scale: $\mathrm{O}=$ healthy; $1=$ symptoms on one cotyledon; 2 = symptoms on both cotyledons; 3 = symptoms on true leaves; $4=$ severe symptoms on true leaves and cotyledons; and 5 = dead.

Field disease severity ratings. In Summer 1983 and 1986, seed of 'Walter', 'Campbell 28', 'Lyconorma', Ohio 4013-3, and Hawaii 7998 were sown in spent coal and transplanted 10 days later to Todd planter flats with $3.8-\mathrm{cm}^{3}$ cells. In Summer 1988, Florida 317 and 325 were included in addition to the lines mentioned above. Transplants were set 1 month later in the field on raised beds of EauGallie fine sand (sandy silicaceous hypothermic Alfic haplaquod). The beds had been fumigated 2 
weeks earlier with $67 \%$ methyl bromide: $33 \%$ chloropicrin at $392 \mathrm{~kg} \cdot \mathrm{ha}-{ }^{1}$ and covered with white polyethylene mulch. Beds were $15 \mathrm{~cm}$ high, $75 \mathrm{~cm}$ wide, and $1.4 \mathrm{~m}$ from center to center. Plants were spaced $61 \mathrm{~cm}$ apart within rows. Genotypes were arranged in a completely randomized design with three replicates and six plants per treatment. Standard fertilizer and insecticide practices were used. Plants were staked, tied, and watered by seepage irrigation. Several weeks after transplanting, plants were inoculated by misting a suspensioncontaining $10^{8} \mathrm{cfu}$ of $X . c$. vesicatorial $\mathrm{ml}$ on the plants with a Solo (Solo Kleinmotoren, Sindelfingen, Germany) backpack sprayer in the early morning. Inoculum was prepared as described previously. Plants were visually assessed 6 weeks after transplanting for defoliation percentage in 1983 and 1986 and by the Horsfall-Barratt scale in 1988.

Comparison of spray-inoculation screening and field disease severity (SSFD) on a plant-by-plant basis. In Summer 1991, seed of Florida $7171(\mathrm{~S}), 896007 \times 896134(\mathrm{R} \times \mathrm{S})$, Hawaii 7998 (R), six resistant parents, and six resulting $\mathrm{F}_{2} \mathrm{~S}$ were sown in spent coal and subsequentlytransplantedtoTodd planter flats, grown for 2 weeks on a greenhouse bench, preconditioned for $16 \mathrm{~h}$, inoculated, incubated, and rated as described for the spray-inoculation seedling screening procedure. There were two replications of control and parental lines with five to eight plants per replication, with the exception of one parent, which had 30 plants in one replication. There were three replications of $\mathrm{F}_{2}$ lines with 10 to 31 plants per replication, with the exception of two lines, which had two replications. Plants were then transplanted to the field $46 \mathrm{~cm}$ apart within the row and subsequently rated for symptom development 10 and 12 weeks later as described for field studies. Beds were $20 \mathrm{~cm}$ high, $81 \mathrm{~cm}$ wide, and $1.5 \mathrm{~m}$ from center to center.

Statistical analyses. Analyses of variance were performed on data and means were separated by Duncan's multiple range test $(P \leq$ $0.05)$, with the exception of the SSFD experiment. $\mathrm{F}$ tests were done on individual experiments for both the spray-inoculation seedling screen and the cotyledon-dip method. All $\mathrm{F}$ values were significant $(P \leq 0.05)$, and experiments were used as replications for data presented in Tables 1 and 2. For the 1983 and 1986 field studies, defoliation percentage ratings ranged from $0 \%$ to $100 \%$ and therefore wereappropriatelytransformedtoarcsin square root for analysis (Gomez and Gomez, 1984). Phenotypic correlations were based on averages rather than individual plant ratings in all experiments with the exception of the SSFD experiment.

\section{Results and Discussion}

In preliminary spray-inoculation seedling screening studies (data not shown), various inoculum concentrations and plant ages were tested to determine which conditions were best suited for accurate seedling screening. About $10^{8} \mathrm{cfu}$ of $X$. c. vesicatoria $/ \mathrm{ml}$ spray-

Table 1. Effectiveness of spray-inoculation seedling screening procedures (preconditioning or nonpreconditioning period) for differentiating bacterial-spot-resistant, partially resistant, and susceptible tomato genotypes.

\begin{tabular}{|c|c|c|c|c|c|}
\hline \multirow[b]{2}{*}{ Genotype/year } & \multirow[b]{2}{*}{ Reaction $^{y}$} & \multicolumn{4}{|c|}{$\begin{array}{c}\text { Disease severity } \\
\text { preconditioning }(\mathrm{h})\end{array}$} \\
\hline & & $0^{x}$ & 8 & 16 & 24 \\
\hline Lyconorma & $\mathrm{S}$ & $2.7 \mathrm{a}^{\mathrm{w}}$ & $2.4 \mathrm{ab}$ & $3.6 \mathrm{a}$ & $2.8 \mathrm{a}$ \\
\hline Walter & $\mathrm{S}$ & $2.1 \mathrm{a}-\mathrm{c}$ & $2.8 \mathrm{a}$ & $3.2 \mathrm{ab}$ & $3.1 \mathrm{a}$ \\
\hline Campbell 28 & PR & $2.3 \mathrm{ab}$ & $2.4 \mathrm{ab}$ & $2.8 \mathrm{bc}$ & $2.4 \mathrm{a}$ \\
\hline Ohio $4013-3$ & PR & $1.4 \mathrm{c}$ & $1.9 \mathrm{bc}$ & $2.3 \mathrm{c}$ & $1.8 \mathrm{a}$ \\
\hline Florida 317 & $\mathrm{R}$ & $1.3 \mathrm{c}$ & $1.2 \mathrm{c}$ & $1.6 \mathrm{~d}$ & $1.8 \mathrm{a}$ \\
\hline Florida 325 & $\mathrm{R}$ & $1.7 \mathrm{bc}$ & $1.8 \mathrm{bc}$ & $1.6 \mathrm{~d}$ & $1.6 \mathrm{a}$ \\
\hline Hawaii 7998 & $\mathbf{R}$ & $1.4 \mathrm{c}$ & $1.5 \mathrm{c}$ & $1.4 \mathrm{~d}$ & $1.6 \mathrm{a}$ \\
\hline \multicolumn{6}{|c|}{ Correlation coefficient $(r)$ with field disease severity ratings } \\
\hline 1983 & & $0.90^{*}$ & 0.82 & $0.91^{*}$ & $0.93^{* *}$ \\
\hline 1986 & & $0.88^{*}$ & 0.76 & $0.94^{* *}$ & $0.87^{*}$ \\
\hline 1988 & & 0.63 & 0.65 & $0.87^{*}$ & 0.72 \\
\hline
\end{tabular}

${ }^{2}$ Disease severity ratings by Horsfall-Barratt scale.

${ }^{y} \mathrm{~S}=$ susceptible; $\mathrm{PR}=$ partially resistant; $\mathrm{R}=$ resistant. Based on previous field evaluations, where ratings were $>5$ for susceptible, intermediate for partially resistant, and $\leq 3$ for resistant genotypes by the HorsfallBarratt scale.

Number of experiments for $0 h=7$, for $8 h=2$, for $16 h=7$, for $24 \mathrm{~h}=2$. Preconditioning refers to placement of plants in a mist chamber with cool-mist humidifiers running continuously for the specified period before inoculation.

"Mean separation within columns by Duncan's multiple range test $(P \leq 0.05)$.

${ }^{*} \cdot{ }^{* *}$ Significance at $P \leq 0.05$ and 0.01 , respectively

inoculated on 2-week-old tomato plants resulted in more disease and better differentiation of genotypes than $10^{6} \mathrm{cfu} / \mathrm{ml}$. Both 2- and 3 -week-old plants provided reliable results, although 2-week-old plants could be inoculated earlier and more evenly with the bacterial suspension.

In spray-inoculation seedling screening experiments designed to compare different periods of preconditioning, all preconditioning periods, except $24 \mathrm{~h}$ (where $P=0.06$ ), differentiated the genotypes (Table 1). At 16 $\mathrm{h}$, resistant genotypes had significantly lower disease ratings than either susceptible genotype. Partially resistant genotypes could only be differentiated from susceptible and resistant plants with the 16-h preconditioning treatment, where partially resistant genotypes had higher ratings than resistant genotypes. When comparing 16-h preconditioning to no preconditioning, the nonpreconditioned $(0-\mathrm{h})$ treatment resulted in more variability and escapes, and a smaller differential between ratings of susceptible and resistant genotypes. With nonpreconditioned plants, resistant genotypes were differentiated from one but not both susceptible genotypes. When plants were preconditioned for $16 \mathrm{~h}$ before inoculation, disease ratings were generally higher with a greater range between susceptible and resistant genotypes. When Davis and Halmos (1958) tested the effect of air moisture on the predisposition of tomato to bacterial spot on one genotype, they concluded that within the limits of their experiment, the longer the plants were exposed to $100 \% \mathrm{RH}$ (up to 2 days before inoculation) the greater their susceptibility to the pathogen. In our experiments, the 16-h treatment resulted in better differentiation of genotypes than the 24-h treatment.

When these data were correlated with three field disease seventy ratings in summer, the 16-h treatment correlated well with all three field experiments, whereas the 0- and 24-h preconditioning treatments were significantly correlated with two field experiments (Table 1). The 8-h treatment ratings did not correlate with field experiments. Our data indicate that the 16-h preconditioning treatment in the seedling screen consistently enhanced genotype discrimination.

Asimilarmethod was developed by Lawson and Summers (1984), in which plants were placed in a box equipped with undescribed misters on a greenhouse bench and held there $24 \mathrm{~h}$ before inoculation and maintained there for $48 \mathrm{~h}$ after inoculation. Several thousand tomato varieties and plant introductions were evaluated, and none were symptomless. They noted that small environmental differences made consistent identification and quantification of susceptible genotypes impossible. Thus, environmental factors are critical and must be

Table 2. Disease ratings from a cotyledon-dip inoculation technique for screening tomato seedlings for resistance to bacterial spot.

\begin{tabular}{lcc}
\hline Genotype $^{z}$ & Reaction $^{\mathrm{y}}$ & Disease ratin $^{x}$ \\
\hline Lyconorma (L) & $\mathrm{S}$ & $2.4 \mathrm{a}^{\mathrm{w}}$ \\
Walter (W) & $\mathrm{S}$ & $1.9 \mathrm{ab}$ \\
Campbell 28 (C) & PR & $2.0 \mathrm{ab}$ \\
Ohio 4013-3 (O) & PR & $2.0 \mathrm{ab}$ \\
Sugar (S) & $\mathrm{S}$ & $1.5 \mathrm{bc}$ \\
W $\times$ H & $\mathrm{S} \times \mathrm{R}$ & $1.1 \mathrm{~cd}$ \\
Florida 325 & $\mathrm{R}$ & $1.1 \mathrm{~cd}$ \\
Florida 317 & $\mathrm{R}$ & $1.0 \mathrm{~cd}$ \\
Hawaii 7998 (H) & $\mathrm{R}$ & $0.8 \mathrm{~d}$
\end{tabular}

${ }^{2}$ Number of experiments for $\mathrm{W}, \mathrm{C}$, and $\mathrm{H}=7$; for Florida 317 and $325=6$; for $\mathrm{L}=4$; for $\mathrm{O}, \mathrm{S}$, and $\mathrm{W} \times \mathrm{H}=3$.

${ }^{\mathrm{y}} \mathrm{S}=$ susceptible; $\mathbf{P R}=$ partially resistant; $\mathrm{R}=$ resistant. Based on field evaluation, where ratings were $>5$ for susceptible, intermediate for partially resistant, and $\leq 3$ for resistant genotypes by the HorsfallBarratt scale.

${ }^{x}$ Disease rating scale: $0=$ healthy; $1=$ symptoms on one cotyledon; 2 = symptoms on both cotyledons; 3 = symptoms on true leaves; $4=$ severe symptoms on true leaves and cotyledons; and $5=$ dead.

"Mean separation within columns by Duncan's multiple range test $(P \leq 0.05)$. 
kept as constant as possible from experiment to experiment to allow comparison across experiments. Lawson and Summers (1984) were able to identify lines with considerable resistance, and although they recommended field evaluations to verify results, comparisons of greenhouse and field results were not reported.

Emmatty et al. (1982) developed a useful seedling screening technique for bacterial speck. Adaptations of this method were tested for their usefulness for bacterial spot screening. In a preliminary experiment, inoculum concentration $\left(10^{8}\right.$ or $8 \times 10^{8} \mathrm{cfu}$ of $X$. c. vesicatoria $/ \mathrm{ml}$ ) did not significantly influence the results (data not shown). In seven cotyledon-dip tests $\left(10^{8} \mathrm{cfu} X\right.$. c. vesicatoria $\left./ \mathrm{ml}\right)$, plant death was infrequent, with the average disease seventy ratings for susceptible genotypes ranging from 1.5 to 2.4 (Table 2). Resistant genotypes could be distinguished from susceptible genotypes, with the exception of 'sugar'.

In our studies, correlations of seven cotyledon-dip experiment ratings with three field seasons were significant for only two of 21 possible field-cotyledon-dip experiment combinations. In contrast, with the spray-inoculation seedling screening procedures (preconditioning and nonpreconditioning), correlations of ratings with the same three seasons of field disease severity were significant for $35 \%$ (19/54) of the possible combinations for all pre- and nonpreconditioned treatments and for $49 \%(16 / 33)$ of the possible combinations of all preconditioned treatments (8-, 16-, and 24-h). These data indicate that preconditioning is superior to nonpreconditioning and more effective than the cotyledon-dip screening technique.

In Summer 1991, individual plants were evaluated by the spray-inoculation seedling screening (16-h preconditioning) method and then were placed in the field to determine susceptibility under field conditions on a plant-by-plant basis (SSFD). Correlations between seedling screening and field ratings were significant $(P \leq 0.0001)$, with $r$ being
0.28 and 0.34 for the first and second field rating, respectively. Where individual seedling screening ratings were less than or equal to a Horsfall-Barratt rating of 3 (selected as resistant based on ratings of Hawaii 7998), $31 \%$ of the field-evaluated plants in the first rating were resistant and $69 \%$ were susceptible. When seedling screening ratings were $>3,10 \%$ of plants in' the field were resistant and $90 \%$ were susceptible. Where plants were rated as $\leq 3$ in the seedling screening rating, $17 \%$ were resistant and $83 \%$ were susceptible in the second field rating. Where the seedling screening rating was $>3,370$ of plants were resistant and $97 \%$ were susceptible in the field. These results indicate that most susceptible plants $(90 \%$ and $97 \%$ in the first and second rating, respectively) can be eliminated before field testing by discarding all plants with a rating $>3$. Thus, the use of the sprayinoculation seedling screening procedure can decrease space, labor, and time and therefore increase the efficiency of tomato improvement programs.

\section{Literature Cited}

Conover,R.A.and N.R. Gerhold. 1981. Mixtures of copper and maneb or mancozeb for control of bacterialspot of tomato and their compatibility for control of fungus diseases, Proc. Fla. State Hort. Soc. 94:154-156.

Coyne, D.P. and M.L. Schuster. 1967. A source of tolerance and reaction of tomato species and varieties to bacterial spot pathogen. Plant Dis. Rptr. 51:25-28.

Crill,P., J.P. Jones, and D.S. Burgis. 1972. Relative susceptibilityofsometomatogenotypes to bacterial spot. Plant Dis. Rptr. 56:504-507.

Davis, D. and S. Halmos. 1958. The effect of air moisture on the predisposition of tomato to bacterial spot. Plant Dis. Rptr. 42:110-111.

Emmatty, D. A., M.D. Schott, and B.F. George. 1982. Inoculationtechniquetoscreen for bacterial speck resistance of tomatoes. Plant Dis. 66:993-994.

Gomez, K.A. and A.A. Gomez. 1984, Statistical procedures for agricultural research. Wiley, New York.
Horsfall,J.G.and R.W. Barratt. 1945. An improved system for measuring plant disease. Phytopathology35:655. (Abstr.)

Jones,J. B., S.M. McCarter, and RD. Gitaitis. 1981. Association of Pseudomonas syringae pv. syringae with a leaf spot disease of tomato transplants in southern Georgia. Phytopathology71:1281-1285.

Lawson, V.F. and W.L. Summers. 1984. Disease reaction of diverse sources of Lycopersicon to Xanthomonas campestris pv. vesicatoria pepper strain race 2. Plant Dis. 68:117-119.

Marco,G.M.and R.E. Stall. 1983. Control of bacterial spot of pepper initiated by strains of Xanthomonas campestris pv. vesicatoria that differ in sensitivity to copper. Plant Dis. 67:779-781.

Russell, D.M. 1992. An inexpensive humidity tent for screening plants against disease. HortScience 27:931.

Scott, J.W. and J.B. Jones. 1986. Sources of resistance to bacterial spot [Xanthomonas campestris pv. vesicatoria (Doidge) Dye] in tomato. HortScience 21:304-306.

Scott, J. W., J.B. Jones, and G. Cameron Somodi. 1989. Genetic resistance to bacterial spot in tomato, p. 200-207, In: S.K. Green (cd.). Tomato and pepper production in the tropics. Asian Veg. Res. \& Dev. Ctr., Shanhua, Taiwan.

Somodi, G. C., J.B. Jones, and J.W. Scott. 1989. Relationship of lesion development on resistant and susceptible tomatoes to internal populations of Xanthomonas campestris pv. vesicatoria, p. 208-21 2. In: S.K. Green (cd.). Tomato and pepper production in the tropics. Asian Veg. Res. \& Dev. Ctr., Shanhua, Taiwan.

Somodi, G. Cameron, J.B. Jones, and J.W. Scott. 1991, Xanthomonas campestris pv. vesicatoria populations in lesions of susceptible and resistant tomato genotypes. Plant Dis. 75:357-360.

Stall, R.E. and P.L. Thayer. 1962. Streptomycin resistance of the bacterial spot pathogen and control with streptomycin. Plant Dis. Rptr. 46:389-392.

Thayer, P.L. and R.E. Stall. 1962. A survey of Xanthomonas vesicatoria resistance to streptomycin. Proc. Fla. State Hort. Soc. 75: 163-165.

Volin, R.B. 1979. Selecting fresh-market tomatoes in Florida for resistance to bacterial leafspot and inheritance studies in improved root development, p. 242-249. In: R. Cowell (cd.). First Intl. Symp. on Tropical Tomato. Asian Veg. Res. \& Dev. Ctr., Shanhua, Taiwan. 